\title{
Kerman weighing electronic lysimeter error analysis
}

\author{
B. Bakhtiari ${ }^{1}$, R. Kamyab Moghadas ${ }^{2}$, M. J. Khanjani ${ }^{3}$ \& H. Taraz ${ }^{2}$ \\ ${ }^{1}$ Agrometeorology, University of Tehran, Irrigation Department, Iran \\ ${ }^{2}$ Iranian Academic Center for Education, Culture and Research, \\ Kerman Branch, Iran \\ ${ }^{3}$ Shahid Bahonar University of Kerman, Iran
}

\begin{abstract}
Lysimeter is an important instrument to measure evapotranspiration in the field of irrigation management. The error analysis and calibration of the system is very critical for quality control of collected data. The error sources are many and different. The Kerman weighing electronic lysimeter is a complex of two cultivation tanks, load cells, data logger, and data processing weighing system with $48 \mathrm{~m}^{2}$ under ground building. In this study, ten-minute interval measured evapotranspiration data were analyzed. The Fourier's series were used to model discrete measured time depended evapotranspiration data. By differentiation of the fitted model the quantity of selected time interval evapotranspiration was computed. By comparing the measured and estimated data the time depended errors were calculated. Computed errors were analyzed, and the statistical distributions of the errors were discussed.

Keywords: evapotranspiration, ET, weighing lysimeter, error analysis, Kerman.
\end{abstract}

\section{Introduction}

Crop evapotranspiration (ET) is a major component of any local hydrologic system. It is an important factor in planning and developing water resources. It should be estimated as correctly as close to avoid any consequence of over or under estimating in local water resources planning. Lysimeter is an instrument to measure actual crop evapotranspiration in field of agricultural irrigation management. It has been used in the United States since the 1930s mainly to measure evapotranspiration (Malone et al. [1]). An excellent summary of 
weighing lysimeter in the United States are presented by Market et al. [2]. After 1970 most constructed lysimeters used load cells to determine mass and have a reported accuracy less than $0.05 \mathrm{~mm}$ which has been suggested as the maximum value necessary to measure hourly ET (Market et al. [2]). According to Allen et al. [3] lysimeter-computed ET is subject to uncertainly, mainly from two sources: measurement uncertainly and representatives of the lysimeter data, although nonrepresentative data may contribute substantially more error. The lysimeter facility provides a unique tool for botanists, agronomists and other plant scientists. By recording information such as soil moisture conditions with in the lysimeter and plant characteristics such as growth rates and maturation it will be possible to more closely evaluate and model the influences of environment on plant growth (Evett et al. [4]). Harrold and Dreibelbis [5] described the lengthy and laborious technique used to obtain the undisturbed monoliths used in the Coshocton, Ohio lysimeter installations. Rapid techniques have been developed to obtain deep undisturbed soil monoliths by pushing cylinders in to the soil. Weighing lysimeter measurements are more reliable method of determining effective rainfall because all components of the water balance are measured. Design factors involved in lysimetry were reviewed by Harrold and Dreibelbis [5]. Two different types of weighing lysimeters have been developed. These involve counterbalancing the dead load (scales approach) of the lysimeter $[6,7]$, or using sensitive load measuring devices $[8,9]$.

In order to measure ET in Kerman area, southeast of Iran, a large weighing lysimeter was built and its data may used to calibrate available ET estimation equations. The over all purpose of this article is to introduce the Kerman weighing electronic lysimeter and by a Fourier's series model to present discrete measured data by continuous equation and to study the residual error of measured and fitted model.

\section{Kerman weighing lysimeter and instrumentation}

Kerman is located at south east of Iran by latitude $30^{\circ}, 15^{\prime}$ and longitude $56^{\circ}, 58^{\prime}$. In order to measure actual evapotranspiration in this area an electronic weighing lysimeter was used. The general concept of a weighing lysimeter requires four major elements. These include the container to hold the soil, water and vegetation; a rigid foundation and house; the force measuring or weighing system; and the data acquisition and analysis system. Accessory instrumentation is also required to measure and record climatic data. The lysimeter designed and installed in this research is illustrated schematically in Figure 1. It consisted of two cylindrical containers. The cylinders contained the soil, water and vegetation, and its weight was measured using three strain gage load cells. One of the load cells and foundations is illustrated in a schematic shown in Figure 2. After installation was completed, undisturbed soil and vegetation was placed on the cylinders and reference crop was placed around the cylinders to restore the original ground surface elevation and vegetation. Cylinder dimensions were selected based on maintaining a suitable diameter to depth ratio (greater than 
one), and the availability of large diameter steel pipe. The cylinder was $1067 \mathrm{~mm}$ in outside diameter with a $9.5 \mathrm{~mm}$ wall thickness and $1372 \mathrm{~mm}$ long. Three load cells are used to translate weighing changes in the lysimeter to voltage changes. Also the data logger and data processing weighing system with $48 \mathrm{~m}^{2}$ under ground building are used. These instruments, measure cultivation cylinders mass in ten-minute intervals, and record them on PC hard disk. An example of hourly printout during a 24-hr period is given in Table 1. Because profile measurements (wind, temperature and moisture) are more easily taken over a very low-growing crop, it was decided that for the first phase of the project reference grass would be used.

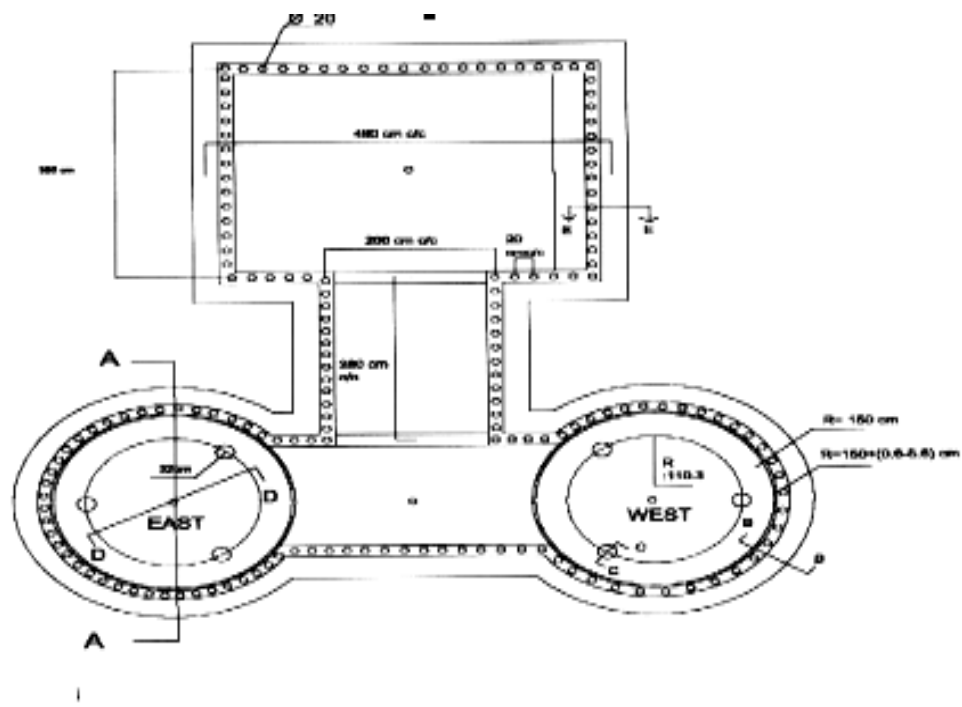

Figure 1: Plan configuration of the lysimeter underground building.

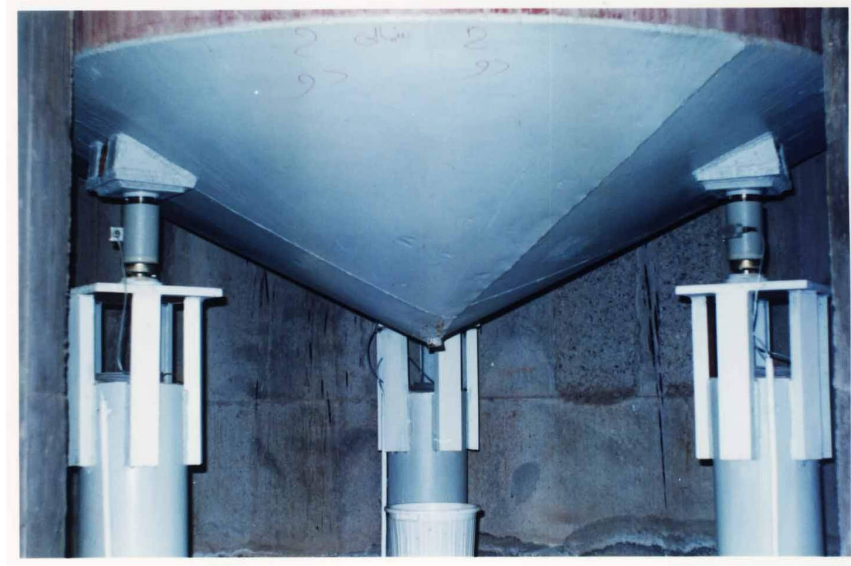

Figure 2: The load cells and foundation of the cylinder. 
Table 1: $\quad$ Example of hourly printout of lysimeter recording system.

\begin{tabular}{|c|c|c|c|c|c|c|c|}
\hline $\begin{array}{c}\text { Date } \\
\text { (d m y) }\end{array}$ & $\begin{array}{c}\text { Time } \\
\text { (h:m) }\end{array}$ & $\begin{array}{c}\text { Relative } \\
\text { Humidity } \\
(\%)\end{array}$ & $\begin{array}{c}\text { Air Temp. } \\
(\mathrm{C})\end{array}$ & $\begin{array}{c}\text { Wind speed } \\
(\mathrm{m} / \mathrm{sec})\end{array}$ & $\begin{array}{c}\text { Wind Direction } \\
\text { (degree) }\end{array}$ & $\begin{array}{c}\text { Weight-North } \\
\text { cylinder } \\
(1000 \mathrm{Kg})\end{array}$ & $\begin{array}{c}\text { Weight-South } \\
\text { cylinder } \\
(1000 \mathrm{Kg})\end{array}$ \\
\hline $01 / 06 / 2002$ & $07: 01$ & 52.9 & 15.2 & 0.2 & 36 & 23.084 & 23.178 \\
$01 / 06 / 2002$ & $07: 11$ & 49.2 & 16.3 & 0.2 & 74 & 23.085 & 23.18 \\
$01 / 06 / 2002$ & $07: 21$ & 46.5 & 17.5 & 0.2 & 57 & 23.085 & 23.179 \\
$01 / 06 / 2002$ & $07: 31$ & 45.6 & 18.1 & 0.2 & 19 & 23.085 & 23.18 \\
$01 / 06 / 2002$ & $07: 41$ & 44.5 & 18.6 & 0.5 & 42 & 23.084 & 23.178 \\
$01 / 06 / 2002$ & $07: 51$ & 44.1 & 19.8 & 0.7 & 45 & 23.085 & 23.18 \\
$01 / 06 / 2002$ & $08: 01$ & 41.7 & 20.5 & 0.7 & 42 & 23.085 & 23.178 \\
$01 / 06 / 2002$ & $08: 11$ & 40.1 & 21 & 0.5 & 77 & 23.084 & 23.178 \\
$01 / 06 / 2002$ & $08: 21$ & 39.6 & 22.2 & 0.6 & 31 & 23.085 & 23.178 \\
$01 / 06 / 2002$ & $08: 31$ & 38.8 & 23.5 & 0.2 & 22 & 23.084 & 23.179 \\
$01 / 06 / 2002$ & $08: 41$ & 39.1 & 23.3 & 0.6 & 24 & 23.084 & 23.178 \\
$01 / 06 / 2002$ & $08: 51$ & 36.5 & 24.2 & 0.6 & 35 & 23.084 & 23.178 \\
\hline
\end{tabular}

\section{Modeling lysimeteric data}

The lysimeter weighing system, measures cultivation cylinders masses in tenminute intervals. Each data points include total measurement error. In order to eliminate random error and built a continue record by discrete data, Fourier's series were used. The suggested model for each day from June1-3, 2002 is:

$$
E T_{C}=\left[C_{1}+C_{2} \times \cos \left(\frac{i j}{T}+C_{3}\right) \times\left(\frac{i j}{T}\right)^{3}+C_{4} \times\left(\frac{i j}{T}\right)^{2}+C_{5} \times\left(\frac{i j}{T}\right)\right] / 7
$$

where $E T_{C}$ is cumulative evapotranspiration $(\mathrm{mm} / \mathrm{hr}), C_{1}$ is phase factor, $C_{2}, C_{3}, C_{4}, C_{5}$ are constant coefficients, $j$ is day of the year (1Jan. $=1$ ), $i$ is hour of the day, $T=\frac{2 \pi}{24 \times 364}$ and 7 is surface of cylinder $\left(\mathrm{m}^{2}\right)$.

Estimated eqn. (1) coefficients by least square method were presented in Table 2. In this model the correlation coefficient in level of $1 \%$ is significant. The observed, fitted curve and their residual data for north and south cylinders for three days are shown in Figure 3.

The suggested model for three days respectively from June 1-3, 2002 is:

$$
E T_{C}=\left\{C_{0}+\sum_{J=1}^{n}\left[C_{1} \times \cos \left[\left(\frac{i j}{T}\right)+C_{2}\right] \times\left(\frac{i j}{T}\right)^{3}+C_{3} \times\left(\frac{i j}{T}\right)^{2}+C_{4} \times\left(\frac{i j}{T}\right)\right]\right\} / 7
$$

The constant coefficient and the observed fitted curve and their residual data for north and south cylinders for three days are shown in Table 3 and Figure 4. 
Table 2: $\quad$ The coefficients of model for three days individually.

\begin{tabular}{|c|c|c|c|c|}
\cline { 2 - 5 } \multicolumn{1}{c|}{} & Date & $01 / 06 / 2002$ & $02 / 06 / 2002$ & $03 / 06 / 2002$ \\
\hline \multirow{2}{*}{ Day of the Year $(\mathrm{J})$} & & 152 & 153 & 154 \\
\cline { 1 - 2 } & Coefficient & & & \\
\cline { 2 - 2 } & C1 & 22963.81 & 23008.95 & 22988.05 \\
& C2 & 27.05 & 14.84 & 18.43 \\
& C3 & 3.79 & 3.60 & 3.76 \\
& C4 & -172.19 & -106.81 & -13.1 .82 \\
R-squared & C5 & 290.009 & 183.76 & 221.94 \\
& & 0.996 & 0.998 & 0.998 \\
\hline \multirow{2}{*}{ South cyl. } & Coefficient & & & \\
\cline { 2 - 2 } & C1 & 23044.26 & 23132.17 & 23111.55 \\
& C2 & 35.98 & 10.94 & 14.35 \\
& C3 & 3.95 & 3.43 & 3.71 \\
& C4 & -211.49 & -76.03 & -102.16 \\
& C5 & 336.14 & 123.86 & 162.04 \\
& & 0.993 & 0.996 & 0.995 \\
\hline
\end{tabular}
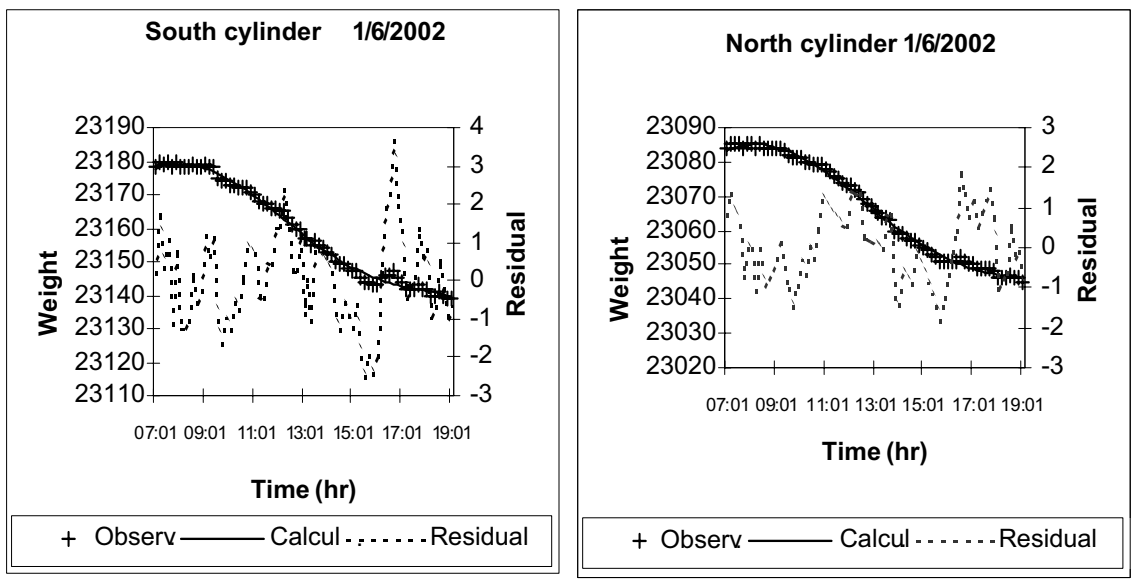

Figure 3: $\quad$ Measure cylinder mass as function of time on June 1, 2002.

\section{Evapotranspiration computation}

By modeling the cylinder time depended on mass reduction by eqn. (1), timely, evapotranspiration was computed by differentially of that equation respect to time. In that order the general differential of eqn. (1) can be written as:

$$
\begin{aligned}
& E T_{i}=E T_{i-1}+\Delta I\left[-C_{2} \times \sin \left(\frac{i j}{T}+C_{3}\right)\left(\frac{i^{3} j^{4}}{T^{4}}\right)\right. \\
& +3 C_{2} \times \cos \left(\frac{i j}{T}+C_{3}\right)\left(\frac{i^{2} j^{3}}{T^{3}}\right)+2 C_{4}\left(\frac{i j^{2}}{T^{2}}\right)+C_{5}\left(\frac{j}{T}\right)
\end{aligned}
$$


Table 3: $\quad$ The coefficient of model for three days respectively.

\begin{tabular}{|c|c|c|c|c|}
\cline { 2 - 5 } \multicolumn{1}{c|}{} & Date & $01 / 06 / 2002$ & $02 / 06 / 2002$ & $03 / 06 / 2002$ \\
\hline North cyl. & Coefficient & $\mathrm{J}=152$ & $\mathrm{~J}=153$ & $\mathrm{~J}=154$ \\
& $\mathrm{C} 0$ & 23004.17 & & \\
& $\mathrm{C} 1$ & 17.038 & 15.98 & 14.18 \\
& $\mathrm{C} 2$ & 3.48 & 3.65 & 3.59 \\
& $\mathrm{C} 3$ & -109.45 & -114.11 & -105.86 \\
& $\mathrm{C} 4$ & 192.76 & 195.18 & 182.41 \\
\hline \multirow{2}{*}{ R-squared } & 0.998 & & & \\
\hline \multirow{2}{*}{ South cyl. } & Coefficient & $\mathrm{J}=240$ & $\mathrm{~J}=241$ & $\mathrm{~J}=242$ \\
\hline & $\mathrm{C} 0$ & 23127.66 & & \\
& $\mathrm{C} 1$ & 13.92 & 11.89 & 10.16 \\
& $\mathrm{C} 2$ & 3.399 & 3.513 & 3.39 \\
& $\mathrm{C} 3$ & -82.076 & -82.88 & -74.53 \\
& $\mathrm{C} 4$ & 135.36 & 134.62 & 121.29 \\
\hline \multirow{2}{*}{ R-squared } & 0.994 & \multicolumn{3}{|c}{} \\
\hline
\end{tabular}
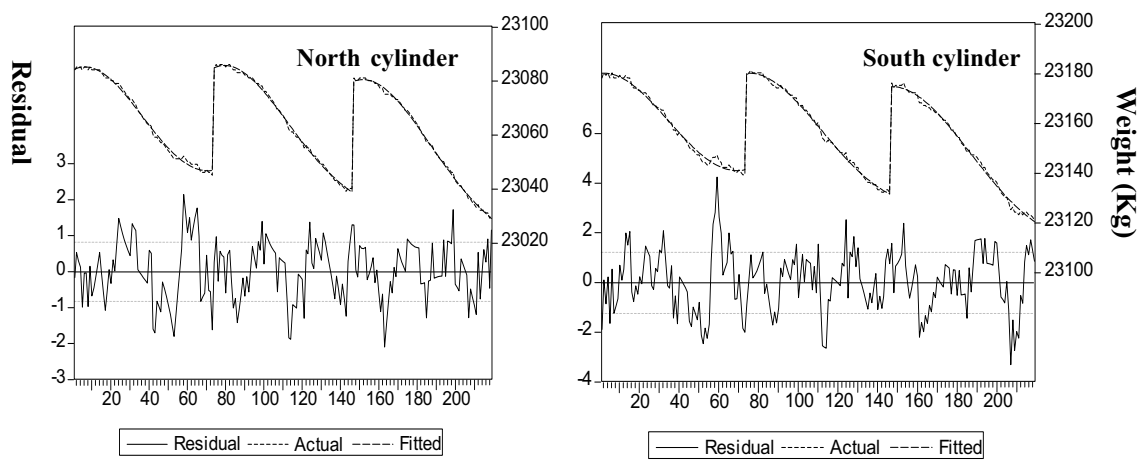

Figure 4: The observed fitted curve and their residuals for two cylinders.

where $E T_{i}$ is evapotranspiration in $i$ th time stage and $\Delta I$ is any time interval.

For $\Delta I$ equal to one hour the hourly ET are computed and shown in Figure 5. These charts show the hourly evapotranspiration for three days under the study. The variation of the ET depends on time of day with different temperature, solar radiation, wind speed and other meteorological parameters.

\section{Error analysis}

The residual error was tested for normality with zero means and 1SD by chi square test [10]. Comparing the theoretical and sample values of the relative frequency or the cumulative frequency function can test the goodness of fit. In 
the case of the relative frequency function, the chi square test statistic $\chi_{C}^{2}$ is given by [10]:

$$
\chi_{C}^{2}=\sum_{i=1}^{m} \frac{n\left[f_{s}\left(x_{i}\right)-p\left(x_{i}\right)\right]^{2}}{p\left(x_{i}\right)}
$$

where: $m$ is the number of intervals, ${ }_{s}\left(x_{i}\right)=\frac{n_{i}}{n}, n_{i}$ is the number of observations in interval $i, p\left(x_{i}\right)=F\left(x_{i}\right)-F\left(x_{i-1}\right)$.
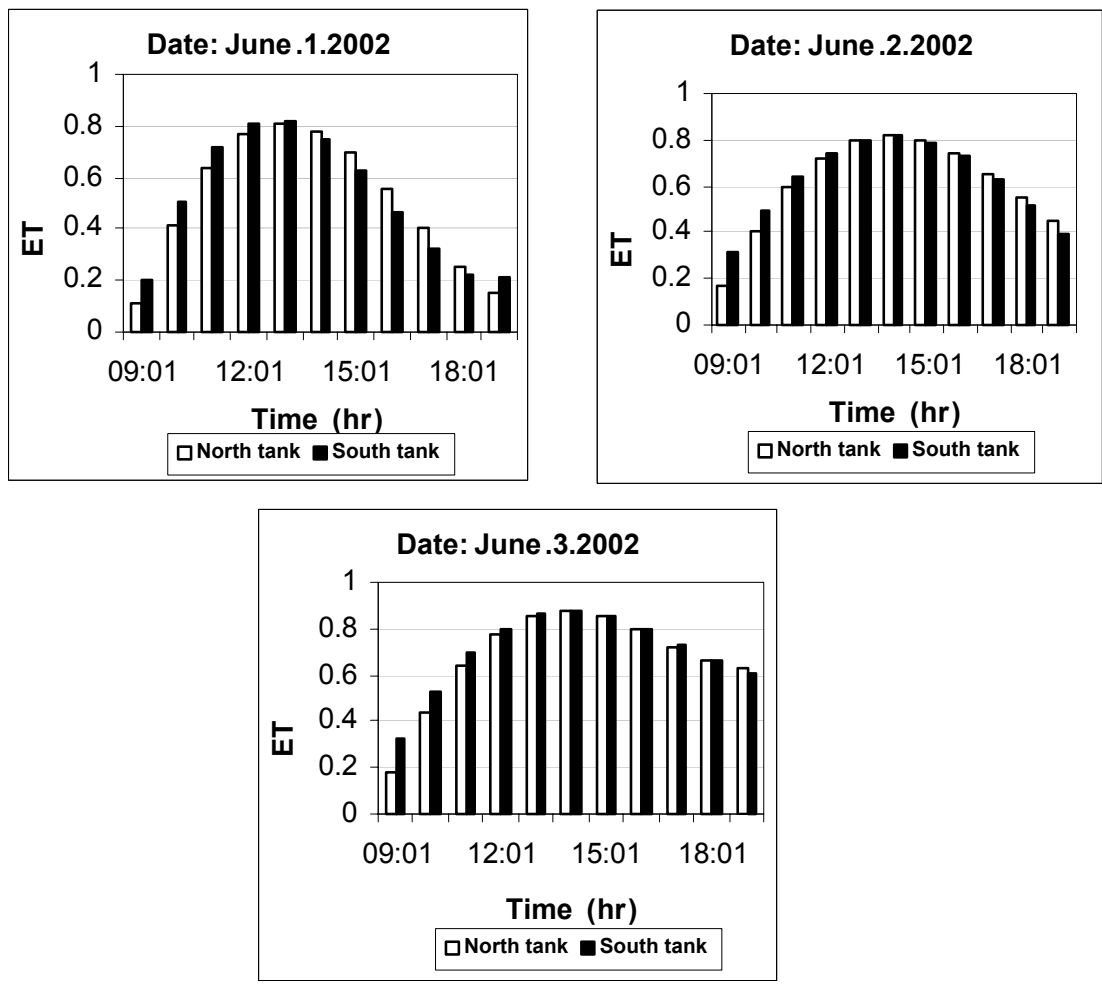

Figure 5: The hourly evapotranspiration $(\mathrm{mm} / \mathrm{hr})$ for three days.

To describe the $\chi^{2}$ test, the $\chi^{2}$ probability distribution must be defined. A $\chi^{2}$ distribution with $v$ degrees of freedom is the distribution for sum of squares

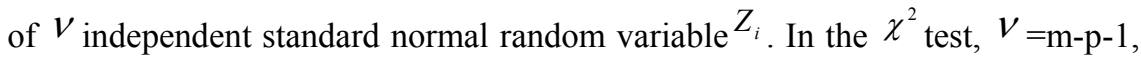
where $\mathrm{m}$ is the number of intervals, and $\mathrm{p}$ is the number of parameters used in fitting the proposed distribution. A confidence level is chosen for the test; it is 
often expressed as $1-\alpha$, where $\alpha$ is termed the significance level: A typical value for the confidence level is 95 percent. The null hypothesis for the test is that the proposed probability distribution fits the data adequately. This hypothesis is rejected if the value of $\chi_{C}^{2}$ is larger than a limiting value, ${ }_{\nu, 1-\alpha}^{2}$, determined from the $\chi^{2}$ distribution with $v_{\text {degrees of freedom as the value }}$ having cumulative probability $1-\alpha$.

For analyzed the computed residual error, the fitting normal distribution was tested. Tables 4 and 5 show the parameters of error analysis lysimeteric data for north and south cylinders. To fit the normal distribution function, the sample statistics $\bar{x}=0.00029$ in and $\mathrm{SD}=1.166$ in are calculated for the residual data for south cylinder. The standard normal variate $Z$ corresponding to the upper limit of each of the data intervals is calculated and shown in Tables 4 and 5.

The relative frequency functions $f_{s}\left(x_{i}\right)$ and $p\left(x_{i}\right)$ from Tables 4 and 5 is plotted in Figure 6 and also the cumulative frequency and probability distribution functions $F_{s}\left(x_{i}\right)$ and $F(x)$ in Figure 6 for north and south cylinders. From the similarity of the two functions shown in each plot, it is apparent that the normal distribution fits these residual data very well. To check the goodness of fit, the $\chi^{2}$ test statistic is calculated by eqn. (4) as shown in column 9 of Table 4 . The total of values in column 9 is $\chi_{c}^{2}=0.0511$. The value of $\chi_{v, 1-\alpha}^{2}$ for a cumulative probability of $1-\alpha=0.95$ and degree of freedom $v=m-p-1=9-2-1=6$ is $\chi_{6,095}^{2}=12.6[10]$. Since this value is greater than $\chi_{c}^{2}$, the distribution fits the residual data cannot be rejected at the 95 percent confidence level; the fit of the normal distribution to the lysimeteric residual data is accepted.

Table 4: $\quad$ Fitting a normal distribution to residual for north cylinder.

\begin{tabular}{|c|c|c|c|c|c|c|c|c|}
\hline $\mathrm{i}$ & Range & $n_{i}$ & $f_{s}\left(x_{i}\right)$ & $F_{s}\left(x_{i}\right)$ & $z_{i}$ & $F\left(x_{i}\right)$ & $p\left(x_{i}\right)$ & $\chi_{c}^{2}$ \\
\hline 1 & $<-2$ & 1 & 0.005 & 0.005 & -2.484 & 0.006 & 0.006 & 0.042 \\
2 & $-2,-1.5$ & 5 & 0.023 & 0.027 & -2.174 & 0.027 & 0.022 & 0.009 \\
3 & $-1.5,-1$ & 21 & 0.096 & 0.123 & -1.553 & 0.123 & 0.096 & 0 \\
4 & $-1,-0.5$ & 35 & 0.160 & 0.283 & -0.932 & 0.283 & 0.160 & 0 \\
5 & $-0.5,0$ & 48 & 0.219 & 0.502 & -0.311 & 0.502 & 0.219 & 0 \\
6 & $0,0.5$ & 41 & 0.187 & 0.690 & 0.310 & 0.690 & 0.187 & $3.6047 \mathrm{E}-30$ \\
7 & $0.5,1$ & 48 & 0.219 & 0.909 & 0.931 & 0.909 & 0.219 & 0 \\
8 & $1,1.5$ & 16 & 0.073 & 0.982 & 1.552 & 0.982 & 0.073 & 0 \\
9 & $>1.5$ & 4 & 0.018 & 1.000 & 1.863 & 1.000 & 0.018 & 0 \\
total & & 219 & & & & & & 0.051 \\
\hline
\end{tabular}

Mean=6.55E-05.

Standard deviation $=0.805$. 
Table 5: $\quad$ Fitting a normal distribution to residual for south cylinder.

\begin{tabular}{|c|c|c|c|c|c|c|c|c|}
\hline $\mathrm{i}$ & Range & $n_{i}$ & $f_{s}\left(x_{i}\right)$ & $F_{s}\left(x_{i}\right)$ & $z_{i}$ & $F\left(x_{i}\right)$ & $p\left(x_{i}\right)$ & $\chi_{c}^{2}$ \\
\hline 1 & $<-3$ & 1 & 0.005 & 0.005 & -2.574 & 0.006 & 0.006 & 0.042 \\
2 & $-3,-2$ & 11 & 0.050 & 0.055 & -2.145 & 0.055 & 0.049 & 0.004 \\
3 & $-2,-1$ & 32 & 0.146 & 0.201 & -1.287 & 0.201 & 0.146 & 0 \\
4 & $-1,0$ & 60 & 0.274 & 0.475 & -0.429 & 0.475 & 0.274 & 0 \\
5 & 0,1 & 76 & 0.347 & 0.822 & 0.429 & 0.822 & 0.347 & 0 \\
6 & 1,2 & 34 & 0.155 & 0.977 & 1.286 & 0.977 & 0.155 & 0 \\
7 & 2,3 & 4 & 0.018 & 0.995 & 2.144 & 0.995 & 0.018 & 0 \\
8 & $>3$ & 1 & 0.005 & 1.000 & 2.573 & 1.000 & 0.005 & $1.48 \mathrm{E}-28$ \\
total & & 219 & & & & & & 0.046 \\
\hline
\end{tabular}

Mean $=0.00029$.

Standard deviation=1.166.
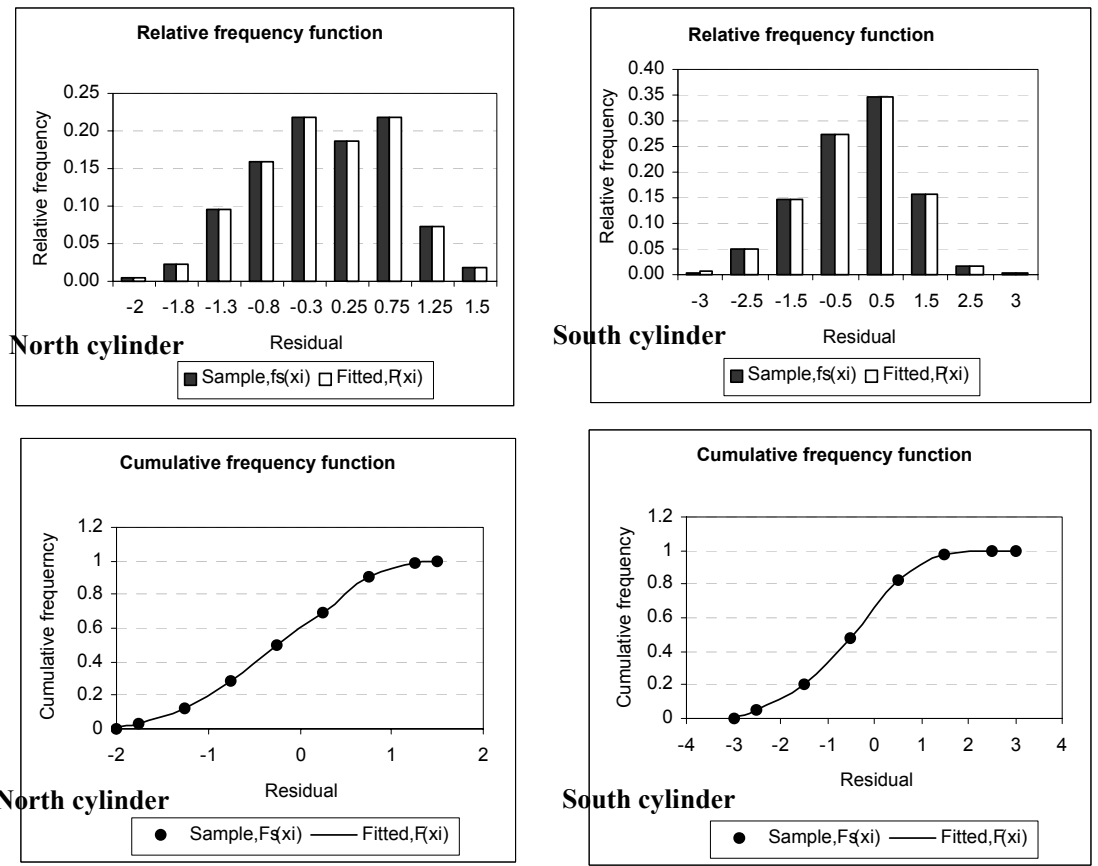

Figure 6: Frequency functions for a normal distribution fitted to residual for north and south cylinders. 


\section{Conclusion}

A lysimeter design has been derived and implemented which will meet the needs of evapotranspiration research for the Kerman province, southeast of Iran. So a large weighing electronic lysimeter was designed, constructed and installed in this area by ACECR- Kerman branch. The parameters of wind disturbance, water infiltration, drainage, thermal continuity, sidewall water percolation, scale stability and safety were considered in the design. Automated cylinder's weight and weather data acquisition were saved in the computer. The main purposes of this article were to present a statistically error analysis for total measurement lysimeteric data. Also in order to estimate random data and built a continuous record by discrete data, the Fourier's series were used and the best model for estimate ET for three days in Kerman was computed. The residual frequency function curves show that the normality distribution fits the residual data at the $95 \%$ confidence level and the fit of the normal distribution at the residual data is accepted. According to Figure 5, the maximum hourly evapotranspiration in Kerman is about $0.8 \mathrm{~mm}$ in 14:00 pm. in pick month June 1-3, 2002.

\section{References}

[1] Malone, R. W., Stewardson, D. J., Bonta, J. V. \& Nelsen, T., Calibration and quality control of the Coshocton weighing lysimeters, ASAE, Vol. 42(3): 701-712, 1999.

[2] Market, T. H., Schneider, A. D., Howell, T. A. \& Ebeling, L. L., Design and construction of large weighing monolithic lysimeters, ASAE, 31(2): 477-484, 1988.

[3] Allen, R. G., Pruitt, W. O. \& Jensen, M. E., Environmental requirements of lysimeters. In lysimeters for evapotranspiration and environmental measurements, eds. R. G. Allen, T. A. Howell, W. O. Pruitt, I. A. Walter, and M. E. Jensen, 170-181. New York, N. Y.: Am. Society of Civil Engineers, 1991.

[4] Evett, S. R., Howell, T. A., Todd, R. W., Schneider, A. D. \& Tolk, J. A., Evapotranspiration of irrigated alfalfa in a semi-arid environment, USDA, 1998.

[5] Harrold, L. L. \& Dreibelbis, F. R., Evaluation of agricultural hydrology by monolith lysimeters, USDA Technical Bulletin. No. 1179, Washington, D. C. 1944-1955, 1958.

[6] Black, T. A., Thurtell, G. W. \& Tanner, C. B. Hydraulic load-cell lysimeter, construction, calibration, and tests, Soil Sci. Soc. Am. J., Vol. 32, pp: 623-29, 1968.

[7] Pruitt, W. O. \& Angus, D. E. Large weighing lysimeter for measuring evapotranspiration, ASAE, Vol. 3, pp: 13-18, 1960.

[8] Armijo, J. D., Twitchell, G. A., Burman, R. D. \& Nunn, J. R., A large, undisturbed, weighing lysimeter for grassland studies, ASAE, Vol. 15, No. 5, pp: 827-30, 1972. 
[9] Dugas, W. A., Upchurch, D. R. \& Ritchie, J. T., A weighing lysimeter for evapotranspiration and root measurements, Agron. Journal, Vol. 77, pp:821-25, 1985.

[10] Charles, Haan, T., Statistical Methods in hydrology. The Iowa state university press, 1977. 